\title{
Comparative airway inflammatory response of normal volunteers to ozone and lipopolysaccharide challenge
}

\author{
Michelle L. Hernandez ${ }^{1}$, Bradford Harris ${ }^{1}$, John C. Lay ${ }^{2}$, Philip A. Bromberg ${ }^{2}$, David Diaz- \\ Sanchez ${ }^{3}$, Robert B. Devlin ${ }^{4}$, Steven R. Kleeberger ${ }^{5}$, Neil E. Alexis ${ }^{2}$, and David B. Peden ${ }^{2}$ \\ ${ }^{1}$ Department of Pediatrics, University of North Carolina at Chapel Hill, Chapel Hill, North Carolina,
} USA

${ }^{2}$ Center for Environmental Medicine, Asthma, and Lung Biology, University of North Carolina at Chapel Hill, Chapel Hill, North Carolina, USA

${ }^{3}$ US Environmental Protection Agency, Chapel Hill, North Carolina, USA

${ }^{4}$ US Environmental Protection Agency, National Health and Environmental Effects Research Laboratory, Research Triangle Park, North Carolina, USA

${ }^{5}$ Environmental Genetics Group, National Institute of Environmental Health Sciences, Research Triangle Park, North Carolina, USA

\section{Abstract}

Ozone and lipopolysaccharide (LPS) are environmental pollutants with adverse health effects noted in both healthy and asthmatic individuals. The authors and others have shown that inhalation of ozone and LPS both induce airway neutrophilia. Based on these similarities, the authors tested the hypothesis that common biological factors determine response to these two different agents. Fifteen healthy, nonasthmatic volunteers underwent a 0.4 part per million ozone exposure for $2 \mathrm{~h}$ while performing intermittent moderate exercise. These same subjects underwent an inhaled LPS challenge with 20,000 LPS units of Clinical Center Reference LPS, with a minimum of 1 month separating these two challenge sessions. Induced sputum was obtained $24 \mathrm{~h}$ before and $4-6 \mathrm{~h}$ after each exposure session. Sputum was assessed for total and differential cell counts and expression of cell surface proteins as measured by flow cytometry. Sputum supernatants were assayed for cytokine concentration. Both ozone and LPS challenge augmented sputum neutrophils and subjects' responses were significantly correlated $(R=.73)$ with each other. Ozone had greater overall influence on cell surface proteins by modifying both monocytes (CD14, human leukocyte antigen [HLA]-DR, CD11b) and macrophages (CD11b, HLA-DR) versus LPS where CD14 and HLA-DR were modified only on monocytes. However, LPS significantly increased interleukin (IL)-1 $\beta$, IL-6, and tumor necrosis factor (TNF)- $\alpha$, with no significant increases seen after ozone challenge. Ozone and LPS exposure in healthy volunteers induce similar neutrophil responses in the airways; however, downstream activation of innate immune responses differ, suggesting that oxidant versus bacterial air pollutants may be mediated by different mechanisms.

C 2010 Informa UK Ltd

Address for Correspondence: Michelle Hernandez, MD, Department of Pediatrics, University of North Carolina at Chapel Hill, 104 Mason Farm Road, Chapel Hill, NC 27599-7310, USA. michelle_hernandez@ med.unc.edu.

Michelle L. Hernandez, Bradford Harris, and John C. Lay contributed equally to this work.

Declaration of interest

The project was supported by Award Number R01ES012706 from the National Institute for Environmental Health Sciences, KL2RR025746 (M.L.H.) and UL1RR025746 from the National Center for Research Resources, and CR 83346301 from the US Environmental Protection Agency. The content is solely the responsibility of the authors and does not necessarily represent the official views of the National Institute for Environmental Health Sciences, the National Center for Research Resources, the National Institutes of Health, or the United States Environmental Protection Agency. 


\section{Introduction}

A wide variety of pollutants have been associated with adverse health effects in healthy populations and those with chronic diseases, such as asthma. Among the most commonly encountered pollutants are ozone $\left(\mathrm{O}_{3}\right)$ and particulate matter. There are a number of mechanisms by which $\mathrm{O}_{3}$ may impact health outcomes. Experimental $\mathrm{O}_{3}$ challenge studies of normal volunteers reveal three effects of ozone: a relatively immediate and temporary restrictive lung function defect, increased airway inflammation, and increased non-specific airway reactivity. The immediate effect of $\mathrm{O}_{3}$ on lung function tends to be of short duration, whereas inflammatory responses can persist at least $24 \mathrm{~h}$, particularly in GSTM1-null individuals (Bernstein et al., 2004; Peden, 2005, 2008).

A significant constituent of particulate matter (PM) is lipopolysaccharide (LPS), which is important in both outdoor and indoor environments. LPS is a prototypic pathogen-associated molecular pattern (PAMP) moiety that activates airway monocytes and macrophages through interaction with CD14 and the Toll-like receptor 4 (TLR4). Inhalation of LPS activates macrophages, which induce neutrophilic inflammation of the airways. We have previously reported that 20,000 EU doses of Clinical Center Reference LPS (CCRE), a level equivalent to that found at many work-places, cause an influx of neutrophils in the airways of both allergic asthmatic and normal volunteers and that there is a strong correlation between the sputum macrophage CD14 expression and LPS-induced polymorphonuclear neurophil (PMN) influx (Alexis et al., 2001).

We have found that inhalation of $\mathrm{O}_{3}$ causes a similar type of airway inflammatory response to that seen with inhaled LPS challenge. Like LPS challenge, $\mathrm{O}_{3}$ inhalation induces airway neutrophilia and increases levels of cytokines (Peden, 2008). In addition, we have reported that following challenge with either $\mathrm{O}_{3}$ or LPS, sputum monocytes and macrophages have increased expression of a number of important cell surface proteins that mediate innate and acquired immune responses, including CD11b, CD14, CD86, and human leukocyte antigen [HLA]-DR (Alexis et al., 2004, 2005, 2008; Lay et al., 2007). $\mathrm{O}_{3}$ and LPS also enhance response to inhaled allergen in allergic subjects (Molfino et al., 1991; Ball, Folinsbee et al., 1996; Jorres et al., 1996; Eldridge and Peden, 2000; Boehlecke et al., 2003; Chen et al., 2004; Schaumann et al., 2008). We hypothesize that increased response to allergen is due, at least in part, to changes in immune regulatory proteins on the surface of airway monocytes and macrophages. We have also reported that pretreatment with inhaled corticosteroids inhibit both $\mathrm{O}_{3}$ and LPS-induced airway inflammation in humans in vivo (Alexis and Peden, 2001; Alexis et al., 2008). Taken together, these observations suggest that $\mathrm{O}_{3}$ and LPS exert similar proinflammatory effects in the airway.

The pathways mediating LPS- and $\mathrm{O}_{3}$-induced airway inflammation share some common features. Response to LPS is mediated to a great extent by interactions between LPS-binding protein, mCD14, sCD14, and TLR4. LPS-binding protein and CD14 bind LPS and facilitate its ligation to TLR4, which initiates MyD88-mediated signaling, ultimately causing nuclear factor (NF)- $\kappa \mathrm{B}$ activation and production of a variety of proinflammatory cytokines, including interleukin (IL)- $1 \beta$ and tumor necrosis factor (TNF)- $\alpha$ (Means et al., 2000; Beutler, 2002; Leung et al., 2005). Although the signaling pathways for $\mathrm{O}_{3}$ are much less well understood, it is known that $\mathrm{O}_{3}$ challenge of epithelial cells results in NF- $\mathrm{\kappa B}$ activation and production of a variety of mediators such as IL-6, IL-8, prostaglandin $\mathrm{E}_{2}\left(\mathrm{PGE}_{2}\right)$, leukotriene $\mathrm{B}_{4}\left(\mathrm{LTB}_{4}\right)$, thromboxane $\mathrm{B}_{2}\left(\mathrm{TXB}_{2}\right)$, fibronectin, plasminogen activator, and elastase (McKinnon et al., 1993; Devlin et al., 1994; Jaspers et al., 1997, 1998; Nichols et al., 2001) Thus, both $\mathrm{O}_{3}$ and LPS likely activate similar pathways to regulate airway inflammation. 
To test the hypothesis that $\mathrm{O}_{3}$ and LPS share similar immunoinflammatory response patterns, we recruited volunteers who completed an $\mathrm{O}_{3}$ study $(0.4 \mathrm{ppm}, 2 \mathrm{~h})$ to undertake an inhalation challenge study to 20,000 EU of LPS. We hypothesized that airway neutrophil responses to $\mathrm{O}_{3}$ would correlate with those to inhaled LPS. As secondary measures, we also examined the comparative effect of $\mathrm{O}_{3}$ and LPS on inflammatory cytokine levels (IL-1 $\beta$, IL-6, IL-8, and TNF- $\alpha$ ) and expression of cell surface proteins CD11b, CD14, CD86, and HLA-DR on airway monocytes and macrophages.

\section{Methods}

\section{Volunteer recruitment and inclusion criteria}

These protocols were reviewed and approved by the University of North Carolina Committee on the Rights of Human Subjects (Institutional Review Board). All subjects underwent a physical examination, a routine blood panel with complete blood count (CBC) and differential and allergy skin testing. Subjects were required to have a negative methacholine challenge. Female subjects had to have a negative urine pregnancy test prior to challenge and all volunteers were required to be free of chronic cardiovascular or respiratory illness, and be free of acute respiratory illness within 4 weeks of $\mathrm{O}_{3}$ challenge. All subjects had forced expiratory volume in one second $\left(\mathrm{FEV}_{1}\right)$ and forced vital capacity $(\mathrm{FVC}) \geq 80 \%$ predicted and $\mathrm{FEV}_{1} / \mathrm{FVC} \geq 75 \%$ predicted normal for height and age, and were nonsmokers with no smoking history. All subjects were screened for their ability to provide an adequate induced-sputum sample during their training session. There was a minimum of 1-month time separating $\mathrm{O}_{3}$ and LPS challenges, with an average of 6 months separating challenge sessions for this cohort of subjects.

\section{Lung function testing}

Spirometry testing was preformed according to American Thoracic Society/European Respiratory Society (ATS/ERS) recommendations using the Viasys VMax 229 series spirometers. All subjects were seated, and at least three maneuvers were obtained, with the best of the three reported.

\section{Ozone exposure and LPS challenge protocols}

Ozone inhalation challenge-The $\mathrm{O}_{3}$ exposures were conducted in an $\mathrm{O}_{3}$ exposure chamber at the US Environmental Protection Agency (EPA) Human Studies Facility on the campus of the University of North Carolina, Chapel Hill, NC. Each subject was exposed to $\mathrm{O}_{3}(0.4 \mathrm{ppm})$ for $2 \mathrm{~h}$ while performing four 15 -min sessions of intermittent moderate exercise (minute ventilation or $\mathrm{VE}_{\min }=30-40 \mathrm{~L} / \mathrm{min}$ ) on a treadmill, separated by $15 \mathrm{~min}$ of seated rest. Spirometry, breath sounds, and vital signs were assessed before and immediately after exposure. Sputum was obtained $4-6 \mathrm{~h}$ postexposure and processed as previously described (Alexis et al., 2003, 2006). Sputum was assessed for total and differential cell counts, flow-cytometric assessmemt of CD11b, CD14, CD86, and HLA-DR on macrophages and monocytes (Lay et al., 2007, 2009). Sputum supernatants were also assessed for cytokine concentration.

\section{LPS (Clinical Center Reference Endotoxin [CCRE]) inhalation challenge-The} study protocol consisted of 3 consecutive days and is similar to protocols previously employed by our group (Alexis et al., 2005, 2009) The first day of each study period was for baseline measurements of spirometry, venipuncture for complete blood count (CBC) analysis, vital signs, symptom score, and induced sputum endpoints. On the second day, baseline spirometry, vital signs, and symptom scores were recorded immediately before inhalation challenge. CCRE (20,000 EU) was provided by the National Institutes of Health Clinical Center and is referred to as Clinical Center Reference Endotoxin (CCRE). 
Spirometry was measured once each hour for $6 \mathrm{~h}$ after the inhalation challenge. Induced sputum was performed $6 \mathrm{~h}$ after the inhalation challenges. After the completion of the induced sputum procedure, vital signs and symptom scores were recorded, and the subjects were observed for $1 \mathrm{~h}$ prior to discharge from the laboratory. Follow-up measurements of spirometry, vital signs, and symptom scores were recorded on the following morning (third day).

\section{Sputum induction and processing}

Subjects provided an induced sputum sample during the screening visit and at $4-6 \mathrm{~h}$ after the $\mathrm{O}_{3}$ exposure, and $6 \mathrm{~h}$ after the inhaled CCRE challenge. Sputum induction and processing methods have been previously described in detail and are referenced in the print article. In brief, three 7-min inhalation periods of nebulized hypertonic saline $(3 \%, 4 \%, 5 \%)$ (DeVilbiss UltraNeb 99 ultrasonic nebulizer) were followed by expectoration of sputum into a sterile specimen cup. A cell-enriched "select" sample was obtained by plucking visible clumps of cells and cell-rich mucus "plugs" from the raw sample to separate them from noncellular portions of the sample. This was then treated with a dilute $(0.1 \%)$ solution of dithiothrietol (DTT; Sputolysin; Calbiochem, San Diego, CA) in Dulbecco's phosphate buffered saline (DPBS) to digest mucus. Following centrifugation $(500 \times g$, for $10 \mathrm{~min})$, aliquots of sputum supernatant were immediately frozen and stored at $-80^{\circ} \mathrm{C}$ and the cell pellet was suspended in a small volume of Hanks balanced salt solution (HBSS). Cell viability (trypan blue exclusion) and total cell counts were assessed in a Neubauer hemacytometer and differential cell counts were performed on cytocentrifuged cells stained with a modified Wright's stain, (Hema-Stain-3; Fisher Scientific). A portion of the cells were immediately used for flow-cytometric assays.

\section{Flow cytometry}

Cell surface markers-Expression of selected cell surface molecules on sputum leukocytes was quantified via multicolor flow cytometry (FCM) using a BD LSR-II flow cytometer (BD Immunocytometry Systems; San Jose, CA). These included molecules associated with antigen presentation and specific immunity (CD86/B7.2, HLA-DR/MHCII,), as well as innate immune function (CD11b/CR3, CD14/LPS receptor). First, sputum leukocytes were differentiated from cellular debris, bacteria, yeast, and squamous and bronchial epithelial cells by gating on CD45 (pan-leukocyte marker)-positive cells. Leukocyte populations were further differentiated by various specific gating strategies based on a combination of light scatter properties (forward scatter [FSC] reflects cell size; side scatter [SSC] reflects cell granularity/density), differential expression of CD45 (panleukocyte marker), and select surface lineage markers. For example, PMNs were defined as CD16 ${ }^{\mathrm{high}} / \mathrm{CD} 64^{\mathrm{dim}} / \mathrm{CD} 14^{\mathrm{dim}} / \mathrm{HLA}-\mathrm{DR}^{\mathrm{dim}}$ cells, whereas monocytes were defined as CD14 ${ }^{\text {high} / C D 64 ~}{ }^{\text {high} / H L A-D R ~}{ }^{\text {high }}$ cells and further differentiated from macrophages by CD45 expression and robust differential SSC expression. Up- or down-regulation of specific surface molecules was quantified as a change in the mean fluorescent intensity (MFI) of the gated population. Fluorochrome-labeled antibodies were obtained from BD Biosciences (CD11b-PE-CY5, CD45-APC-Cy7, HLADR- PerCP) and Beckman-Coulter (CD14-APC, CD86-PE). Appropriate, nonspecific, labeled isotypic control antibodies were also obtained from these sources. Monocyte cell counts were determined using percentages within the monocyte gate as determined by fluorescence-activated cell sorting (FACS) analysis, together with the total cell count as determined from hemacytometry. Unlike macrophages, monocyte quantification was not based on microscopically read cytospin slides. 


\section{Mediator measurement}

Cytokines from sputum supernatants were measured using multiplex technology (Meso ScaleDiscovery/MSD, Gaitherburg, MD). Each sample was analyzed with the HumanMIP-1 alpha Ultra Sensitive Kit (lot no. K0031370) and the Human TH1/TH2 10-Plex Ultra Sensitive Kit (lot no. K0031431). All supernatant samples were diluted 1:4 and had a final dithiothreitol (DTT) concentration of $<1 \mathrm{mM}$ where no deleterious effects have been observed using the MSD platform.

\section{Statistical analysis}

Change in cell counts/mg, differential percentage (sputum), mean fluorescence intensity measures (flow cytometry), and cytokine values pre- and post- $\mathrm{O}_{3}$ and LPS exposures was analyzed using the nonparametric paired Wilcoxon signed rank test. Correlations between $\mathrm{O}_{3}$ and LPS (CCRE) responses for each outcome measure (responses defined as fold change from baseline values) were assessed using the Spearman correlation technique $(R)$.

Significance was set at $p=.05$ for all tests.

\section{Results}

\section{Subject characteristics}

Demographic data for 15 healthy volunteers who completed a challenge study to $0.4 \mathrm{ppm} \mathrm{O}_{3}$ and were then recruited for challenge with 20,000 EU of CCRE are presented in Table 1. Four subjects were atopic as defined by positive skin prick testing to a panel of environmental allergens, though none were symptomatic at the time of either $\mathrm{O}_{3}$ or CCRE challenge.

\section{General response to $\mathrm{O}_{3}$ and CCRE}

Challenge to both $\mathrm{O}_{3}$ and CCRE were well tolerated, with no adverse events being observed in any of these volunteers. Immediately following exposure to $\mathrm{O}_{3}$ the $\mathrm{FVC}$ was $88.2 \% \pm$ $1.5 \%$ of baseline and the $\mathrm{FEV}_{1}$ was $84.15 \% \pm 1.8 \%$ of baseline, with full recovery occurring by $24 \mathrm{~h}$. This is an expected response to $\mathrm{O}_{3}$. There was no significant effect of inhaled CCRE on lung function.

\section{Effect of $\mathrm{O}_{3}$ and $\mathrm{CCRE}$ on airway neutrophilia}

As shown in Figure 1A, we found that both $\mathrm{O}_{3}$ and CCRE resulted in a significant increase over baseline of $\%$ PMNs $\left(\mathrm{O}_{3}: 42.1 \% \pm 5.0 \%\right.$ versus $63.9 \% \pm 3.9 \%, p=.0002$; CCRE: $33.02 \% \pm 6 \%$ versus $49.20 \% \pm 4 \%, p=.02$ ). The absolute number of neutrophils (PMNs/ $\mathrm{mg}$ ) were significantly increased above baseline following $\mathrm{O}_{3}$ challenge $(766.1 \pm 278.0$ versus $1237 \pm 329.6, p=.003$ ) and elevated following CCRE but not significantly above baseline (633.8 \pm 293.7 versus $810.6 \pm 396.6)$, as denoted in Figure 1B. The total cell counts and absolute numbers of leukocyte subsets as well as percentages are shown in Table 2.

\section{Cytokine responses to $\mathrm{O}_{3}$ and CCRE}

Of the sputum samples recovered from volunteers, we generally had adequate sample to assess sputum cytokines from a majority of the 15 volunteers who underwent $\mathrm{O}_{3}$ and CCRE challenge. Specifically, we examined the effect of these agents on sputum IL-1 $\beta$ ( $n=14$ for $\mathrm{O}_{3}, n=12$ for CCRE), IL-6 ( $n=12$ for both $\mathrm{O}_{3}$ and CCRE), IL-8 ( $n=13$ for $\mathrm{O}_{3}$ and $n=11$ for CCRE), and TNF- $\alpha$ ( $n=14$ for $\mathrm{O}_{3}$ and $n=12$ for CCRE). No significant increases in any of these cytokines were observed after $\mathrm{O}_{3}$ challenge. CCRE challenge resulted in significant increases in IL-1 $\beta$, IL-6, and TNF- $\alpha$. These results are shown in Figure 2. 


\section{Changes in monocyte and macrophage cell surface proteins following challenge with $\mathrm{O}_{3}$ and CCRE}

Of the sputum samples recovered from volunteers, we generally had adequate sample to assess changes in selected cell surface proteins on sputum monocytes and macrophages from a majority of the 15 volunteers who underwent $\mathrm{O}_{3}$ and CCRE challenge. Specifically, we assessed the effect of $\mathrm{O}_{3}$ and CCRE on expression of monocyte and macrophage CD11b, CD14, CD86, and HLA-DR. The effect of $\mathrm{O}_{3}$ and CCRE on surface protein expression on monocytes and macrophages are depicted in Figures 3 and 4, respectively. In general, monocytes exhibited greater changes in surface protein to either stimulus than macrophages. CD11b was significantly increased only after $\mathrm{O}_{3}$ challenge in both monocytes and macrophages.

\section{Correlation of the neutrophil response following $\mathrm{O}_{3}$ and CCRE challenge}

We examined the correlation of the neutrophil response following $\mathrm{O}_{3}$ and CCRE challenge in 13 subject pairs. The neutrophil response was measured as the fold change from baseline in 13 subject pairs for \% PMNs and PMNs/mg sputum. Linear regression analysis was performed and a best-fit line was generated for the data. There was a significant correlation in \% PMNs in induced sputum. The strength of the correlation was affected by inclusion of an outlier, whose \% PMNs at baseline for the CCRE challenge session (46.8\%) was elevated compared to her baseline value for ozone challenge (16\%). We speculate that she may have had a subclinical viral infection. With inclusion of this outlier, the $r$ value was .59 , with a $p$ value of .03. Figure 5 shows a regression line generated without the outlier $(r=.73, p=$. 007). The outlier is denoted by an open circle. This correlation did not hold for PMNs/mg $(r$ $=.14, p=.65$ ). Correlation analyses applied to other differential cells (macrophages) and cell surface proteins such as monocyte CD14 $(r=-.2, p=.6, N=11$ pairs $)$ and HLA-DR $(r$ $=.42, p=.23, N=11$ pairs) revealed no significant associations between $\mathrm{O}_{3}$ and CCRE.

\section{Discussion}

Ozone and LPS are both known to induce airway inflammation following inhalation challenge. As noted in the Introduction, there are a number of similarities between the airway responses of these two agents in humans, including airway neutrophilia, changes in surface marker expression on airway monocytes and macrophages, and production of proinflammatory cytokines. Mechanistic studies in animals suggest that at least some responses to $\mathrm{O}_{3}$ are mediated through TLR4, the primary LPS receptor. Kleeberger and colleagues used LPS responsive $\mathrm{CH} 3 / \mathrm{HeOuJ}$ mice and LPS-resistant HeJ mice that differ only at a polymorphism in the coding region of TLR4 to determine the effect of TLR4 on response to $\mathrm{O}_{3}$ (Kleeberger et al., 2000; Cho and Kleeberger, 2007). They found that one response phenotype, airway hyperpermeability, was increased in the $\mathrm{CH} 3 / \mathrm{HeOuJ}$ mice, suggesting that TLR4 modulates this response to $\mathrm{O}_{3}$. Hollingsworth et al. used mice in which TLR4 had been deleted and compared response to LPS and $\mathrm{O}_{3}$ (Hollingsworth et al., 2004). They found that acute neutrophilia following LPS, but not $\mathrm{O}_{3}$, was ablated in the TLR4-deficient mice, but that airway reactivity following subacute $\mathrm{O}_{3}$ exposure was decreased in TLR4-deficient mice compared to wild-type mice. Taken together, these observations suggest that TLR4 may modulate at least some $\mathrm{O}_{3}$-induced responses.

In this study, we examined the airway inflammatory response of 15 human volunteers to 0.4 ppm $\mathrm{O}_{3}$ and 20,000 EU CCRE (LPS) in order to directly compare an individual's response to these two agents, and to determine if there was a correlation between these responses. Such a correlation would be consistent with the hypothesis that common biological factors determine response to these two different agents. We chose these levels of $\mathrm{O}_{3}$ and LPS because we have previously found that they induce similar levels of sputum neutrophilia, a 
robust marker of airways inflammation, while avoiding undesirable systemic side effects to our study population. We also chose a 4-6-h time point after both exposure sessions in order to be able to make direct comparisons between exposures. Schelegle et al. showed that the percent of neutrophils in proximal airway samples with BAL was maximal $6 \mathrm{~h}$ after a 0.3 ppm $\mathrm{O}_{3}$ exposure, compared to 1 and $24 \mathrm{~h}$ after $\mathrm{O}_{3}$ exposure (Schelegle et al., 1991). Our group has previously shown maximal percent neutrophils as well as neutrophils/mg of sputum after a $0.4 \mathrm{ppm} \mathrm{O}_{3}$ exposure in induced sputum at $6 \mathrm{~h}$ compared to $24 \mathrm{~h}$ (Lay et al., 2007) without segregating for GSTM1 genotype, as was the case for the current study. Studies examining the time course after LPS challenge are more limited; a 60- $\mu$ g inhaled LPS challenge induced maximal induced sputum neutrophilia (PMNs/ml) in normal volunteers at $24 \mathrm{~h}$ after LPS challenge compared to baseline or 6-h values, with no difference in \% neutrophils compared to baseline at the 6- and 24-h time points (Nightingale et al., 1998). Because of the substantial difference in a 60- $\mu \mathrm{g}$ dose of LPS compared to our equivalent of a 5- $\mu \mathrm{g}$ dose, it is difficult to speculate if comparison of sputum neutrophilia or other markers at a 24 -h time point would have significantly changed our findings.

In this study, we found that both agents increased percent neutrophils in sputum compared to baseline values. The fold change in \% neutrophils between $\mathrm{O}_{3}$ and LPS was the only variable that was significantly correlated among individuals. Cell surface protein responses such as CD14 and HLA-DR were not correlated even though both were significantly increased following $\mathrm{O}_{3}$ and LPS challenge. One possible explanation may be that the range of surface marker response following LPS challenge was more limited compared to $\mathrm{O}_{3}$. Indeed we found that fold change from baseline of CD14 and HLA-DR was greater with $\mathrm{O}_{3}$ exposure than with LPS challenge. Correlations would be more difficult to determine under these circumstances and would have required a larger sample size than that used here. The 4-6-h time point used in our study also presents another significant limitation in determining these correlations, as these cell surface markers could potentially have been further modified with time.

In general, the dose of $\mathrm{O}_{3}$ used in this study generated a more vigorous cellular response than LPS in terms of neutrophil recruitment to the airways and cell surface marker expression on both monocytes and macrophages. This observation may be accounted for by the dose of LPS used in our human challenge exposure protocols. Michel and colleagues have shown that much higher doses of inhaled LPS (50 $\mu \mathrm{g}$ LPS, approximately 10 times the dose used in our study) elicited robust neutrophil responses in induced sputum (Michel et al., 1997) equivalent to those with $0.4 \mathrm{ppm} \mathrm{O}_{3}$ used in this study. However, this higher dose of LPS has been shown to produce systemic side effects such as elevations in temperature and subjective symptoms, thereby limiting its use in human subjects. It can be argued that the differences in response to these agents may also be due to differences in inflammatory signaling by stimuli that directly activate macrophages as opposed to exposures that can cause sterile tissue injury. Devlin et al. showed that healthy volunteers who underwent a 2-h $0.4 \mathrm{ppm} \mathrm{O}_{3}$ exposure had evidence of tissue injury, such as elevated lactate dehydrogenase $(\mathrm{LDH})$ and protein, in their bronchoalveolar lavage fluid at 1 and $18 \mathrm{~h}$ after the exposure (Devlin et al., 1996). The increased PMN response to $\mathrm{O}_{3}$ relative to LPS noted in our study may be due to a broader range of inflammatory signaling induced by injury to the airway epithelium and its extracellular matrix, such as via the release of hyaluronic acid (Manzanares et al., 2007), which interacts with TLR4 (Taylor et al., 2007; Garantziotis et al., 2009), and through the release of potent neutrophil chemoattractants such as IL-8 and LTB4 (McKinnon et al., 1993; Devlin et al., 1994). Although LPS exposure will activate airway macrophages through its interaction with TLR4, we have not shown that challenge with 20,000 EU CCRE augments levels of IL-8 in induced sputum (Alexis et al., 2005). 
Interestingly LPS caused a greater effect on cytokine levels than $\mathrm{O}_{3}$. There are two potential explanations for this difference in response. The first may be temporally related to our sampling time. Devlin et al. showed that IL-6 and $\mathrm{PGE}_{2}$ levels were higher $1 \mathrm{~h}$ after exposure than $18 \mathrm{~h}$ after a 2-h 0.4 ppm O 3 exposure (Devlin et al., 1996). We sampled induced sputum 4-6 h after the end of the 2-h $\mathrm{O}_{3}$ exposure session, potentially impairing our ability to sample IL-6 or other relevant cytokines at their peak levels. We have shown that particulate matter containing LPS appears to initiate proinflammatory cytokine production at a slower rate, where macrophage mRNA TNF- $\alpha$, but not protein, was detected $2 \mathrm{~h}$ after the end of the exposure (Alexis et al., 2006). We routinely sample induced sputum supernatants for protein $6 \mathrm{~h}$ after a CCRE challenge because of this time lag in cytokine production with LPS.

Another possibility to explain the differences in cytokine profiles following these challenges is likely due to signal transduction cascades responding to $\mathrm{O}_{3}$ versus LPS challenge. The increased IL-1 $\beta$, IL- 6 , and TNF- $\alpha$ levels following LPS (versus $\mathrm{O}_{3}$ ) challenge may occur because these cytokines are more strongly associated with macrophage response than with epithelial cell responses. Both \% macrophages and the absolute number of macrophages were greater following LPS than $\mathrm{O}_{3}$ challenge (Table 2); LPS activation of a greater number of airway macrophages could account in large part for this enhanced cytokine response because the number of macrophages significantly exceeded the number of monocytes following LPS challenge (data not shown). Collectively, our data suggest that injury to airway tissues by $\mathrm{O}_{3}$ likely results in the production of a cascade of mediators, which results in more robust airway neutrophilia, whereas the effects of LPS inhalation may be more limited to macrophage activation in the airway. It will be informative in the future to compare these mediator levels at later time points, as the late-phase cytokine milieu may provide further clues as to potentially shared and/or distinct airway inflammatory responses to these two pollutants.

Both agents resulted in recovery of monocytes from sputum with increased expression of CD14 and HLA-DR, and a trend for increased CD86 expression. Whereas CD11b and HLADR were increased in both monocytes and macrophages after $\mathrm{O}_{3}$ challenge, CD14 and CD86 were relatively unaffected. This suggests that macrophages, as compared to newly recruited monocytes, are less likely to undergo phenotype modification from $\mathrm{O}_{3}$ and LPS. This may be a function of their already mature state in the airways and hence committed phenotype, whereas monocytes have a less committed phenotype and are vulnerable to modifying agents. The increased expression of cell surface proteins that mediate antigen presentation (HLA-DR, CD86) following both $\mathrm{O}_{3}$ and LPS are indeed consistent with our own observations that show that $\mathrm{O}_{3}$ and inhaled LPS enhance response to inhaled allergen (Boehlecke et al., 2003; Peden, 2008). Furthermore, we have shown that the number of monocytes with modified surface phenotypes are elevated following $\mathrm{O}_{3}$ exposure, resulting in an overall increased antigen-presenting capability in the airways (Lay et al., 2007).

Although we only saw direct correlations between neutrophil responses to $\mathrm{O}_{3}$ and LPS, common risk factors may still modulate response and adverse health effects associated with exposure to both $\mathrm{O}_{3}$ and LPS. A number of candidate genetic factors have been identified which may modulate response to a variety of pollutants and irritants (London, 2007). The $\mathrm{O}_{3}$ protocol from which volunteers were recruited for this study was focused on the examination of the role of the GSTM1-null genotype in modulating response to ozone. We found that GSTM1-null volunteers had increased airway inflammation $24 \mathrm{~h}$ after completion of the challenge than did those who were sufficient in GSTM1 (Alexis, Zhou et al., 2009). In addition to modulating the response to $\mathrm{O}_{3}$, GSTM1-null individuals have been reported to have increased susceptibility to diesel exhaust (Gilliland et al., 2004) and tobacco smoke (Gilliland et al., 2002, 2006). 
Although LPS is not an oxidant per se, cells activated by LPS do generate oxidants, and overall responses to LPS likely involve oxidant-dependent mechanisms. The GSTM1 gene is among a large number of antioxidant and cell defense genes regulated by the transcription factor nuclear erythroid 2 p45-related factor 2 (NRF2) (Kensler et al., 2007). We could not identify reports examining GSTM1 as a modulator of response to LPS. However, there are reports demonstrating that cellular responses to LPS are modified by NRF2 (Thimmulappa et al., 2006), and NRF2-deficient mice are much more sensitive to the effect of experimental sepsis induced by LPS than are wild-type mice (Thimmulappa et al., 2006). Thus, GSTM1 or other NRF2-regulated genes may be candidate genes that modulate response to LPS as well as $\mathrm{O}_{3}$. Our study included 15 individuals, 8 of whom were GSTM1+ and 7 of whom were GSTM1-. Although this sample size is too limited to make meaningful conclusions about the effect of GSTM1 status on LPS responses, it will be important to examine this genotype in a larger study population to define the effect of antioxidant defense genes on LPS-induced airway inflammation.

To our knowledge, this is the first study in which healthy volunteers underwent challenge with $\mathrm{O}_{3}$ and LPS to compare the inflammatory responses to these two agents within the same individuals. Our results indicate that an individual's ability to generate a neutrophil response in the airways following $\mathrm{O}_{3}$ exposure is significantly associated with their ability to do the same following inhaled LPS challenge. Moreover, both pollutants up-regulate mCD14 and HLA-DR on sputum monocytes. However, the cytokine milieu is not shared by these two pollutants. In summary, we report that $\mathrm{O}_{3}$ and LPS induce neutrophilic inflammation and modify markers of innate immunity. These observations, coupled with these pollutants' ability to augment response to inhaled allergen in allergic volunteers, suggest that other common mechanisms need to be explored to fully understand the risk factors associated with these two agents.

\section{References}

Alexis NE, Peden DB. Blunting airway eosinophilic inflammation results in a decreased airway neutrophil response to inhaled LPS in patients with atopic asthma: A role for CD14. J Allergy Clin Immunol. 2001; 108:577-580. [PubMed: 11590384]

Alexis N, Eldridge M, Reed W, Bromberg P, Peden DB. CD14-dependent airway neutrophil response to inhaled LPS: Role of atopy. J Allergy Clin Immunol. 2001; 107:31-35. [PubMed: 11149987]

Alexis NE, Eldridge MW, Peden DB. Effect of inhaled endotoxin on airway and circulating inflammatory cell phagocytosis and CD11b expression in atopic asthmatic subjects. J Allergy Clin Immunol. 2003; 112:353-361. [PubMed: 12897742]

Alexis NE, Lay JC, Almond M, Peden DB. Inhalation of low-dose endotoxin favors local T(H)2 response and primes airway phagocytes in vivo. J Allergy Clin Immunol. 2004; 114:1325-1331. [PubMed: 15577830]

Alexis NE, Lay JC, Almond M, Bromberg PA, Patel DD, Peden DB. Acute LPS inhalation in healthy volunteers induces dendritic cell maturation in vivo. J Allergy Clin Immunol. 2005; 115:345-350. [PubMed: 15696093]

Alexis NE, Lay JC, Zeman K, Bennett WE, Peden DB, Soukup JM, Devlin RB, Becker S. Biological material on inhaled coarse fraction particulate matter activates airway phagocytes in vivo in healthy volunteers. J Allergy Clin Immunol. 2006; 117:1396-1403. [PubMed: 16751003]

Alexis NE, Lay JC, Haczku A, Gong H, Linn W, Hazucha MJ, Harris B, Tal-Singer R, Peden DB. Fluticasone propionate protects against ozone-induced airway inflammation and modified immune cell activation markers in healthy volunteers. Environ Health Perspect. 2008; 116:799-805. [PubMed: 18560537]

Alexis NE, Zhou H, Lay JC, Harris B, Hernandez ML, Lu TS, Bromberg PA, Diaz-Sanchez D, Devlin RB, Kleeberger SR, Peden DB. The glutathione- $S$-transferase Mu 1 null genotype modulates ozone-induced airway inflammation in human subjects. J Allergy Clin Immunol. 2009 
Ball BA, Folinsbee LJ, Peden DB, Kehrl HR. Allergen bronchoprovocation of patients with mild allergic asthma after ozone exposure. J Allergy Clin Immunol. 1996; 98:563-572. [PubMed: 8828534]

Bernstein JA, Alexis N, Barnes C, Bernstein IL, Nel A, Peden D, Diaz-Sanchez D, Tarlo SM, Williams PB. Health effects of air pollution. J Allergy Clin Immunol. 2004; 114:1116-1123. [PubMed: 15536419]

Beutler B. TLR4 as the mammalian endotoxin sensor. Curr Top Microbiol Immunol. 2002; 270:109120. [PubMed: 12467247]

Boehlecke BM, Hazucha, Alexis NE, Jacobs R, Reist P, Bromberg PA, Peden DB. Low-dose airborne endotoxin exposure enhances bronchial responsiveness to inhaled allergen in atopic asthmatics. $\mathrm{J}$ Allergy Clin Immunol. 2003; 112:1241-1243. [PubMed: 14657891]

Chen LL, Tager IB, Peden DB, Christian DL, Ferrando RE, Welch BS, Balmes JR. Effect of ozone exposure on airway responses to inhaled allergen in asthmatic subjects. Chest. 2004; 125:23282335. [PubMed: 15189958]

Cho HY, Kleeberger SR. Genetic mechanisms of susceptibility to oxidative lung injury in mice. Free Radic Biol Med. 2007; 42:433-445. [PubMed: 17275675]

Devlin RB, McKinnon KP, Noah T, Becker S, Koren HS. Ozone-induced release of cytokines and fibronectin by alveolar macrophages and airway epithelial cells. Am J Physiol. 1994; 266(6 Pt 1):L612-L619. [PubMed: 8023949]

Devlin RB, McDonnell WF, Becker S, Madden MC, McGee MP, Perez R, Hatch G, House DE, Koren HS. Time-dependent changes of inflammatory mediators in the lungs of humans exposed to 0.4 ppm ozone for $2 \mathrm{hr}$ : A comparison of mediators found in bronchoalveolar lavage fluid $1 \mathrm{and} 18 \mathrm{hr}$ after exposure. Toxicol Appl Pharmacol. 1996; 138:176-185. [PubMed: 8658507]

Eldridge MW, Peden DB. Allergen provocation augments endotoxin-induced nasal inflammation in subjects with atopic asthma. J Allergy Clin Immunol. 2000; 105:475-481. [PubMed: 10719296]

Garantziotis S, Li Z, Potts EN, Kimata K, Zhuo L, Morgan DL, Savani RC, Noble PW, Foster WM, Schwartz DA, Hollingsworth JW. Hyaluronan mediates ozone-induced airway hyperresponsiveness in mice. J Biol Chem. 2009; 284:11309-11317. [PubMed: 19164299]

Gilliland FD, Li YF, Dubeau L, Berhane K, Avol E, McConnell R, Gauderman WJ, Peters JM. Effects of glutathione $S$-transferase M1, maternal smoking during pregnancy, and environmental tobacco smoke on asthma and wheezing in children. Am J Respir Crit Care Med. 2002; 166:457-463. [PubMed: 12186820]

Gilliland FD, Li YF, Saxon A, Diaz-Sanchez D. Effect of glutathione-S-transferase M1 and P1 genotypes on xenobiotic enhancement of allergic responses: Randomised, placebo-controlled crossover study. Lancet. 2004; 363:119-125. [PubMed: 14726165]

Gilliland FD, Li YF, Gong H Jr, Diaz-Sanchez D. Glutathione $S$-transferases M1 and P1 prevent aggravation of allergic responses by secondhand smoke. Am J Respir Crit Care Med. 2006; 174:1335-1341. [PubMed: 17023730]

Hollingsworth JW 2nd, Cook DN, Brass DM, Walker JK, Morgan DL, Foster WM, Schwartz DA. The role of Toll-like receptor 4 in environmental airway injury in mice. Am J Respir Crit Care Med. 2004; 170:126-132. [PubMed: 15020293]

Jaspers I, Flescher E, Chen LC. Ozone-induced IL-8 expression and transcription factor binding in respiratory epithelial cells. Am J Physiol. 1997; 272(3 Pt 1):L504-L511. [PubMed: 9124608]

Jaspers I, Chen LC, Flescher E. Induction of interleukin- 8 by ozone is mediated by tyrosine kinase and protein kinase A, but not by protein kinase C. J Cell Physiol. 1998; 177:313-323. [PubMed: 9766528]

Jorres R, Nowak D, Magnussen H. The effect of ozone exposure on allergen responsiveness in subjects with asthma or rhinitis. Am J Respir Crit Care Med. 1996; 153:56-64. [PubMed: 8542163]

Kensler TW, Wakabayashi N, Biswal S. Cell survival responses to environmental stresses via the Keap1-Nrf2-ARE pathway. Annu Rev Pharmacol Toxicol. 2007; 47:89-116. [PubMed: 16968214]

Kleeberger SR, Reddy S, Zhang LY, Jedlicka AE. Genetic susceptibility to ozone-induced lung hyperpermeability: Role of toll-like receptor 4. Am J Respir Cell Mol Biol. 2000; 22:620-627. [PubMed: 10783135] 
Lay JC, Alexis NE, Kleeberger SR, Roubey RA, Harris BD, Bromberg PA, Hazucha MJ, Devlin RB, Peden DB. Ozone enhances markers of innate immunity and antigen presentation on airway monocytes in healthy individuals. J Allergy Clin Immunol. 2007; 120:719-722. [PubMed: 17586033]

Lay JC, Alexis NE, Zeman KL, Peden DB, Bennett WD. In vivo uptake of inhaled particles by airway phagocytes is enhanced in patients with mild asthma compared with normal volunteers. Thorax. 2009; 64:313-320. [PubMed: 19052052]

Leung TF, Tang NL, Wong GW, Fok TF. CD14 and toll-like receptors: Potential contribution of genetic factors and mechanisms to inflammation and allergy. Curr Drug Targets Inflamm Allergy. 2005; 4:169-175. [PubMed: 15853738]

London SJ. Gene-air pollution interactions in asthma. Proc Am Thorac Soc. 2007; 4:217-220. [PubMed: 17607002]

Manzanares D, Monzon ME, Savani RC, Salathe M. Apical oxidative hyaluronan degradation stimulates airway ciliary beating via RHAMM and RON. Am J Respir Cell Mol Biol. 2007; 37:160-168. [PubMed: 17395888]

McKinnon KP, Madden MC, Noah TL, Devlin RB. In vitro ozone exposure increases release of arachidonic acid products from a human bronchial epithelial cell line. Toxicol Appl Pharmacol. 1993; 118:215-223. [PubMed: 8442000]

Means TK, Golenbock DT, Fenton MJ. The biology of Toll-like receptors. Cytokine Growth Factor Rev. 2000; 11:219-232. [PubMed: 10817965]

Michel O, Nagy AM, Schroeven M, Duchateau J, Neve J, Fondu P, Sergysels R. Dose-response relationship to inhaled endotoxin in normal subjects. Am J Respir Crit Care Med. 1997; 156(4 Pt 1):1157-1164. [PubMed: 9351616]

Molfino NA, Wright SC, Katz I, Tarlo S, Silverman F, McClean PA, Szalai JP, Raizenne M, Slutsky AS, Zamel N. Effect of low concentrations of ozone on inhaled allergen responses in asthmatic subjects. Lancet. 1991; 338:199-203. [PubMed: 1676776]

Nichols BG, Woods JS, Luchtel DL, Corral J, Koenig JQ. Effects of ozone exposure on nuclear factorkappaB activation and tumor necrosis factor-alpha expression in human nasal epithelial cells. Toxicol Sci. 2001; 60:356-362. [PubMed: 11248148]

Nightingale JA, Rogers DF, Hart LA, Kharitonov SA, Chung KF, Barnes PJ. Effect of inhaled endotoxin on induced sputum in normal, atopic, and atopic asthmatic subjects. Thorax. 1998; 53:563-571. [PubMed: 9797755]

Peden, D. Air Pollution: Indoor and outdoor. In: Adkinson, NF., Jr; Busse, W.; Bochner, B.; Holgate, S.; Simons, FE.; Lemanske, R., editors. Middleton's Allergy: Principles and Practice. St Louis: Mosby; 2008. p. 495-508.

Peden DB. The epidemiology and genetics of asthma risk associated with air pollution. J Allergy Clin Immunol. 2005; 115:213-219. quiz 220. [PubMed: 15696070]

Schaumann F, Muller M, Braun A, Luettig B, Peden DB, Hohlfeld JM, Krug N. Endotoxin augments myeloid dendritic cell influx into the airways in patients with allergic asthma. Am J Respir Crit Care Med. 2008; 177:1307-1313. [PubMed: 18388357]

Schelegle ES, Siefkin AD, McDonald RJ. Time course of ozone-induced neutrophilia in normal humans. Am Rev Respir Dis. 1991; 143:1353-1358. [PubMed: 2048824]

Taylor KR, Yamasaki K, Radek KA, Di Nardo A, Goodarzi H, Golenbock D, Beutler B, Gallo RL. Recognition of hyaluronan released in sterile injury involves a unique receptor complex dependent on Toll-like receptor 4, CD44, and MD-2. J Biol Chem. 2007; 282:18265-18275. [PubMed: 17400552]

Thimmulappa RK, Lee H, Rangasamy T, Reddy SP, Yamamoto M, Kensler TW, Biswal S. Nrf2 is a critical regulator of the innate immune response and survival during experimental sepsis. J Clin Invest. 2006a; 116:984-995. [PubMed: 16585964]

Thimmulappa RK, Scollick C, Traore K, Yates M, Trush MA, Liby KT, Sporn MB, Yamamoto M, Kensler TW, Biswal S. Nrf2-dependent protection from LPS induced inflammatory response and mortality by CDDO-Imidazolide. Biochem Biophys Res Commun. 2006b; 351:883-889.

[PubMed: 17097057] 

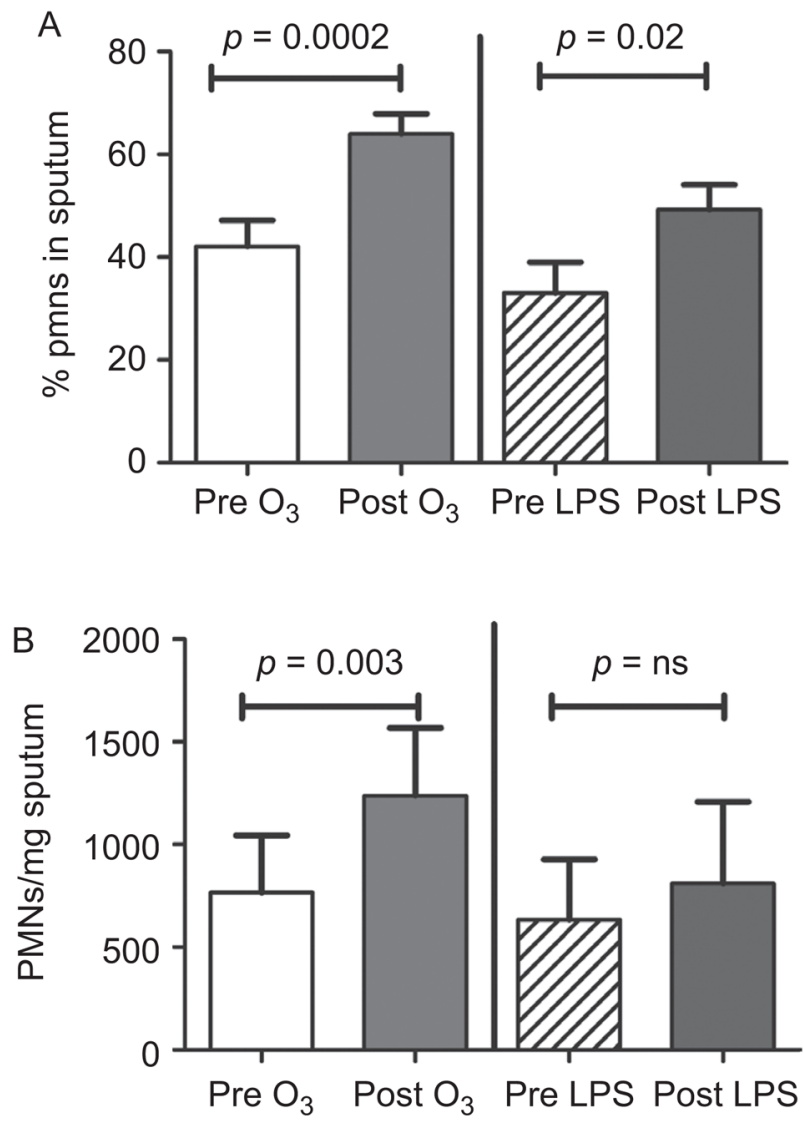

Figure 1.

Neutrophil responses comparing $\mathrm{O}_{3}$ and CCRE challenge. Baseline values are labeled as pre- $\mathrm{O}_{3}$ and pre-LPS. $\mathrm{O}_{3}$ and CCRE exposure both increased $\%$ neutrophils in induced sputum (A), whereas only ozone significantly increased neutrophils per milligram of sputum (B). (See colour version of this figure online at www.informahealthcare.com/ipi) 

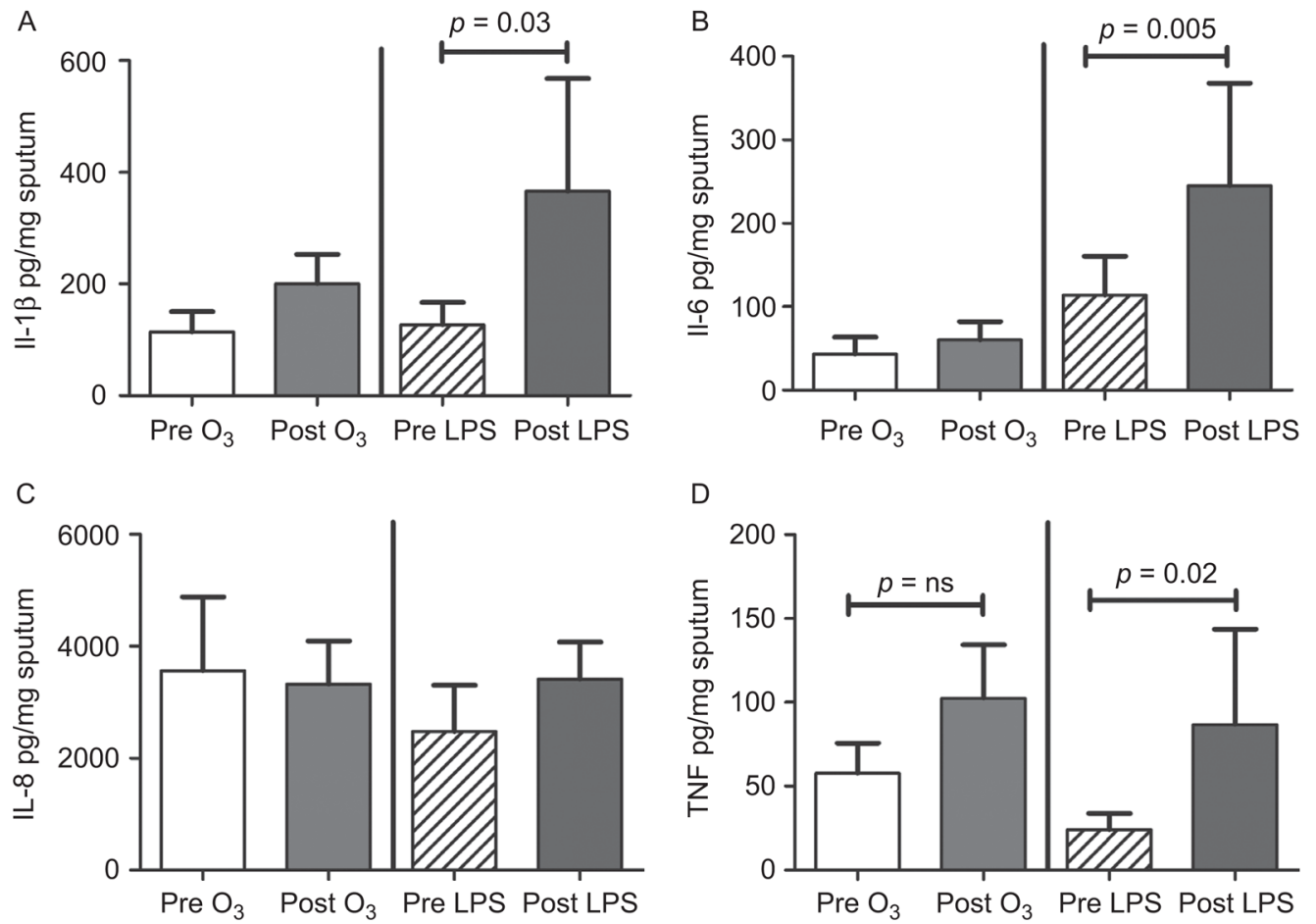

Figure 2.

Cytokines from sputum supernatants comparing $\mathrm{O}_{3}$ and CCRE challenge. Baseline values are labeled as pre- $\mathrm{O}_{3}$ and pre-LPS. Only CCRE challenge significantly increased the concentration of IL-1 $\beta$ (A), IL-6 (B), and TNF- $\alpha$ (D). Neither $\mathrm{O}_{3}$ nor CCRE challenge changed levels of IL-8 (C). (See colour version of this figure online at www.informahealthcare.com/ipi) 


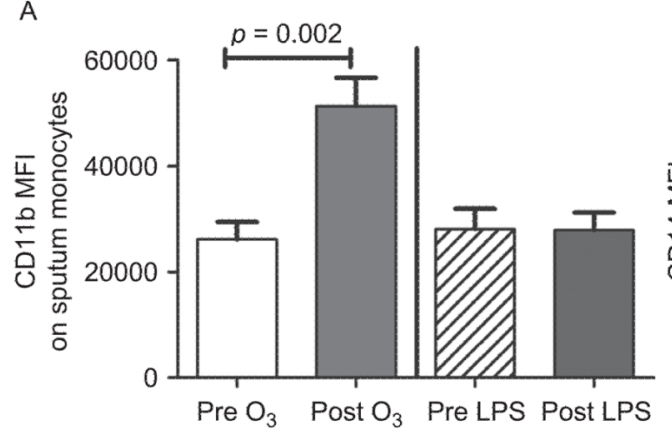

C

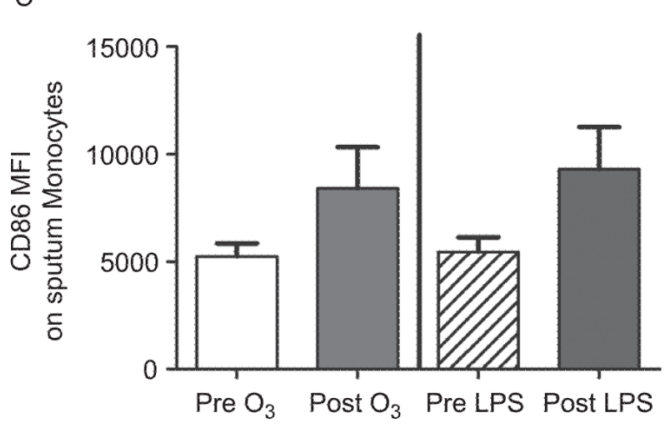

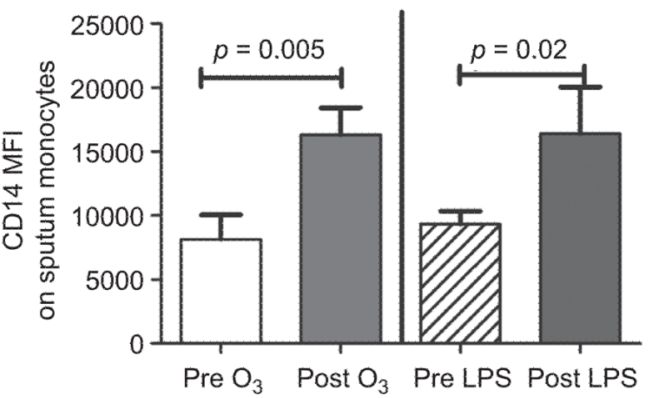

D

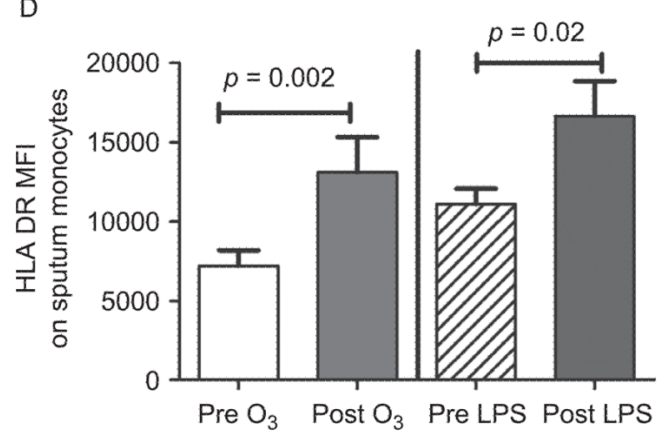

Figure 3.

Cell surface markers of sputum monocytes comparing $\mathrm{O}_{3}$ and $\mathrm{CCRE}$ challenge. Baseline values are labeled as pre- $\mathrm{O}_{3}$ and pre-LPS. CD11b (A) was up-regulated by $\mathrm{O}_{3}$ alone. CD14 (B) and HLA-DR (D) were up-regulated by $\mathrm{O}_{3}$ and CCRE. Neither challenge modality upregulated CD86 (C). CD11b $n=12$ for $\mathrm{O}_{3}$ and $n=12$ for CCRE; CD14 $n=14$ for $\mathrm{O}_{3}$ and $n$ $=12$ for CCRE; CD86 $n=13$ for $\mathrm{O}_{3}$ and $n=11$ for CCRE; and HLA-DR $n=13$ for $\mathrm{O}_{3}$ and $n=12$ for CCRE. (See colour version of this figure online at www.informahealthcare.com/ipi) 
A

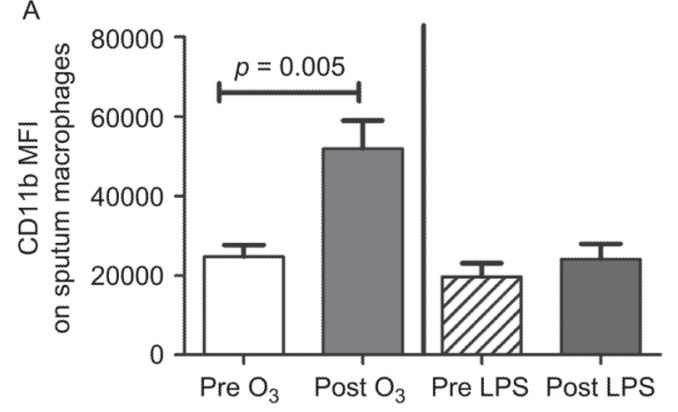

C

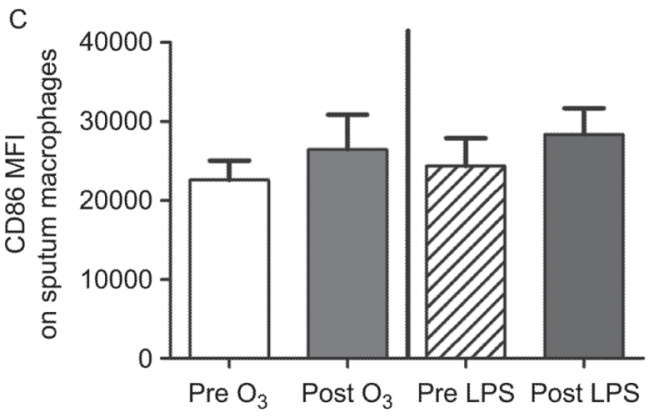

B

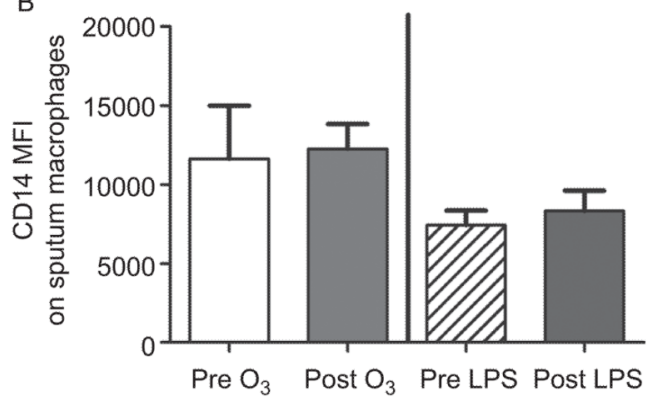

D

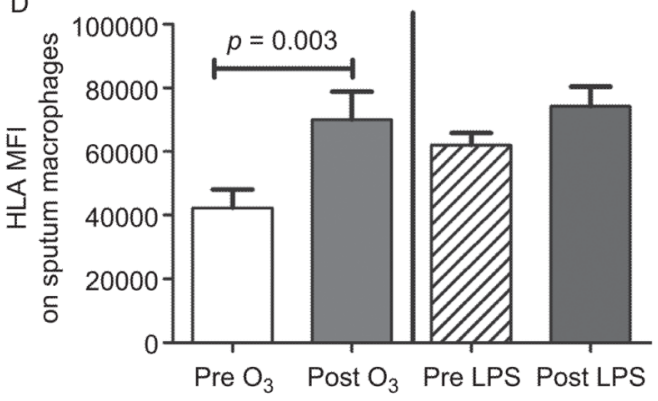

Figure 4.

Cell surface markers of sputum macrophages comparing $\mathrm{O}_{3}$ and CCRE challenge. Baseline values are labeled as pre- $\mathrm{O}_{3}$ and pre-LPS. CD11b (A) and HLA-DR (D) were up-regulated by $\mathrm{O}_{3}$ alone, whereas CD14 (B) and CD86 (C) were not affected by $\mathrm{O}_{3}$ or CCRE challenge. $\mathrm{CD} 11 \mathrm{~b} n=11$ for $\mathrm{O}_{3}$ and $n=12$ for CCRE; CD14 $n=12$ for $\mathrm{O}_{3}$ and $n=12$ for CCRE; CD86 $n=11$ for $\mathrm{O}_{3}$ and $n=11$ for CCRE; and HLA-DR $n=12$ for $\mathrm{O}_{3}$ and $n=12$ for CCRE.(See colour version of this figure online at www.informahealthcare.com/ipi) 


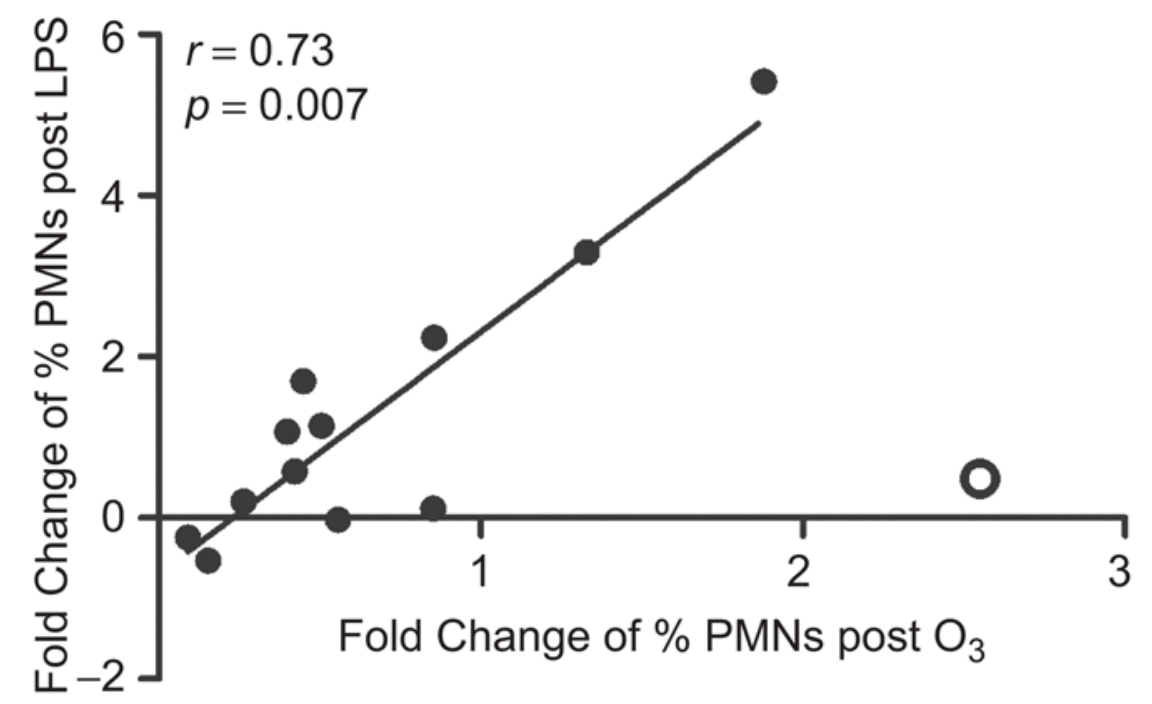

Figure 5.

Correlation analysis comparing fold change from baseline $\%$ neutrophils in induced sputum. $x$-axis denotes $\mathrm{O}_{3}$ challenge and y-axis denotes CCRE (LPS) challenge. $N=12$ pairs to generate the linear regression line. A positive correlation was noted between ozone- and LPS-induced sputum neutrophilia $(r=.73, p=.007)$. With inclusion of the outlier denoted by the open circle, $r=.59, p=.03$. 
Table 1

Study demographics.

\begin{tabular}{ccccl}
\hline & Age & Gender \\
$N$ & Mean $( \pm \boldsymbol{S D})$ & Female/Male & Race & Atopy status (+ Skin prick testing) \\
\hline 15 & $25.3( \pm 5.3)$ & $9 \mathrm{~F} / 6 \mathrm{M}$ & $\begin{array}{c}\text { 13 Caucasian } \\
\text { 1 African American } \\
\text { 1 Latino }\end{array}$ & $\begin{array}{l}\text { 4 atopic } \\
\text { 11 nonatopic }\end{array}$ \\
\hline
\end{tabular}




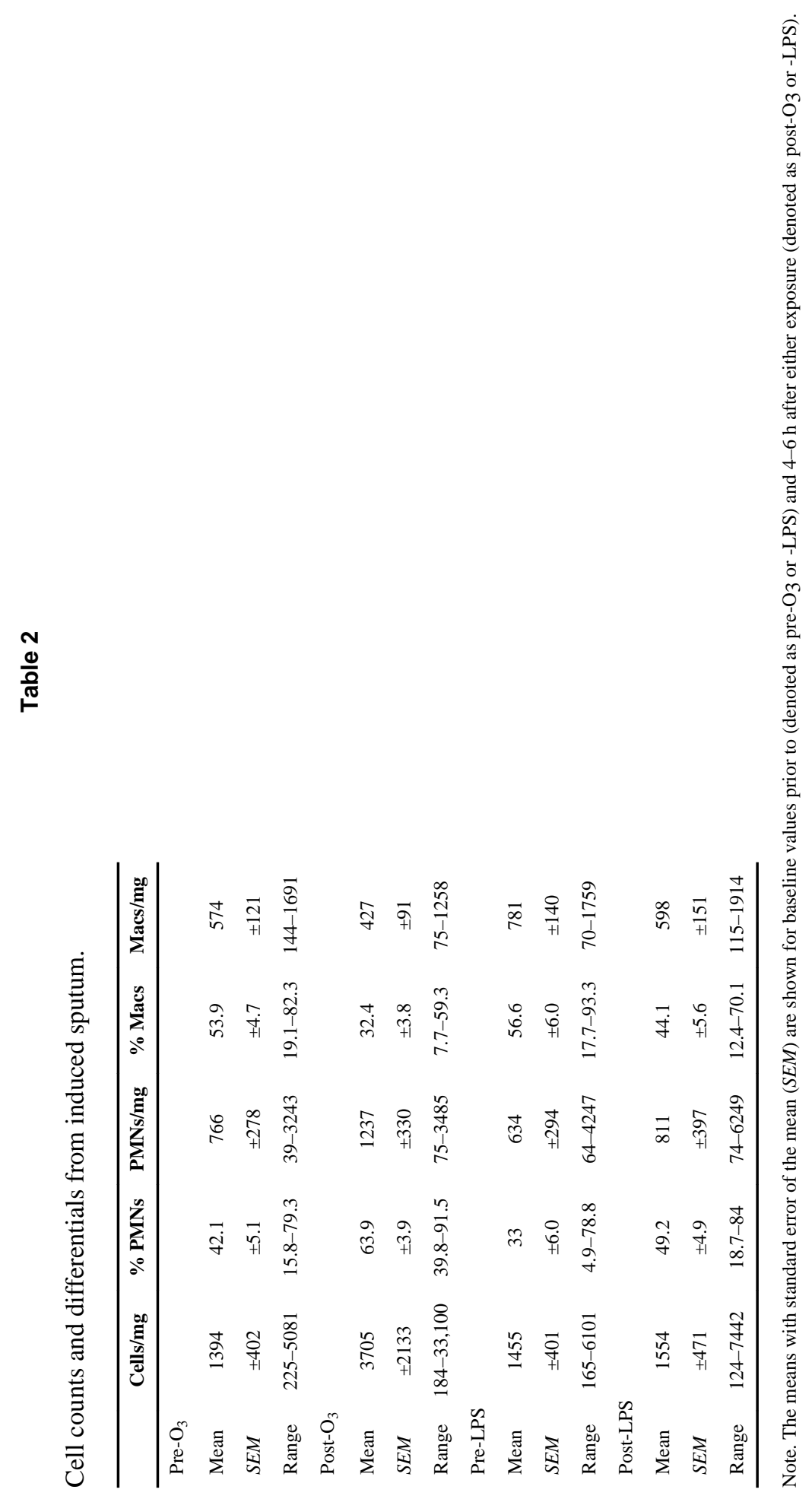

Inhal Toxicol. Author manuscript; available in PMC 2011 August 26. 